\title{
Motivasi Tindakan Penelantaran Tanah (Kasus di Kota Bandar Lampung)
}

\author{
Ima Wulandari ${ }^{1 *}$, Retno Widodo Dwi Pramono ${ }^{2}$ \\ ${ }^{1}$ Mahasiswa, Magister Perencanaan Wilayah dan Kota, Fakultas Teknik, Universitas Gadjah Mada \\ ${ }^{2}$ Dosen, Magister Perencanaan Wilayah dan Kota, Fakultas Teknik, Universitas Gadjah Mada \\ *Penulis Korespondensi: imawulandari@mail.ugm.ac.id
}

\begin{abstract}
Abstrak:
Tanah terlantar menjadi salah satu isu penyimpangan masalah pertanahan di Indonesia. Agar penyimpangan tersebut tidak terjadi, maka perlu tindakan pengendalian pertanahan berupa pemantauan dan evaluasi terhadap penggunaan dan pemanfaatan hak atas tanah. Penyimpangan masalah pertanahan salah satunya terjadi di Kota Bandar Lampung dimana Hak Guna Bangunan yang melanggar penggunaan dan pemanfaatan tanahnya mencapai $23 \%$ dari 133 jumlah bidang Hak Guna Bangunan. Dengan mengambil kasus di Kota Bandar Lampung, penelitian ini bertujuan untuk mengidentifikasi faktor-faktor yang menyebabkan terjadinya tanah terlantar dari berbagai stakeholder. Metode yang digunakan dalam penelitian ini menggunakan pendekatan induktif kualitatif dengan analisis kategorisasi. Data penelitian diperoleh dari pengumpulan data primer dan data sekunder. Data primer diperoleh dari hasil observasi di lapangan, wawancara dengan stakeholder, dan dokumentasi lapangan, serta data sekunder diperoleh dari studi pustaka dan data dari instansi terkait. Hasil penelitian menunjukkan bahwa faktor-faktor yang menyebabkan terjadinya tanah terlantar oleh pemegang hak diakibatkan 1) Faktor Ekonomi, 2) Faktor Institusi, dan 3) Faktor Sosial-Hukum
\end{abstract}

Kata Kunci: hak guna bangunan; motif; tanah terlantar

\section{Latar Belakang}

Tanah kosong di perkotaan menjadi isu berkala di dunia (Gobster, dkk., 2020). Tanah kosong yang diterlantarkan oleh pemilik tanah dapat berdampak pada lingkungan dan masyarakat yang tinggal di sekitarnya (Gobster, dkk., 2020). Tindakan penelantaran tanah di perkotaan dapat terjadi akibat pemegang hak baik sengaja maupun tidak sengaja menelantarkan tanahnya (Ardiwijaya, dkk., 2015). Di Indonesia, penelantaran tanah juga menjadi permasalahan penting akibat ketimpangan pemanfaatan dan penguasaan hak atas tanah yang tidak berimbang (Mujiburohman, 2019). Seharusnya hak atas tanah yang telah diberikan oleh Negara disertai bukti kepemilikan tanah kepada perseorangan atau badan hukum dapat dimanfaatkan dan dikelola secara optimal. Negara mempunyai kewenangan untuk mengatur penggunaan tanah dan akses terhadap tanah berdasarkan hak kepemilikan tanahnya (Sumardjono, 2009). Kewenangan negara untuk mempertegas, mengatur dan menertibkan penggunaan hak atas tanah dilakukan merujuk pada Undang-Undang Pokok Agraria tahun 1960. Namun jika penggunaan hak atas tanah tetap belum dimanfaatkan sesuai pemberian haknya maka berdasarkan Peraturan Pemerintah Nomor 11 Tahun 2010 perlu dilakukan upaya penertiban dan pendayagunaan tanah terlantar. Tanah terlantar yang menjadi tanah negara tersebut didayagunakan untuk kepentingan masyarakat dan negara melalui Reforma Agraria, program strategis negara dan cadangan negara sesuai dalam Peraturan Kepala Badan Pertanahan Nasional RI Nomor 04 Tahun 2010.

Penelitian-penelitian oleh Ardiwijaya, dkk., 2015; Gobster dkk., 2020; Ilmiawan, 2016; Li, 2014 dan Gao \& Ma, 2015 juga berorientasi terhadap tanah terlantar. Penelitian Li, (2014), lebih berfokus kepada penyebab penelantaran di pedesaan akibat topografi wilayah yang tidak mendukung, minimnya tenaga kerja, tingginnya tingkat urbanisasi dan pendapatan petani rendah. Hal serupa juga dibahas oleh Gao \& Ma (2015) yang melihat penelantaran tanah dilatar belakangi oleh rendahnya pengawasan dari institusi, tanah dibiarkan terlantar terlalu lama dan adanya kepemilikan tanah bersama. Ilmiawan, (2016) lebih melihat faktor fisik, ekonomi dan institusi sebagai penyebab utama penelantaran tanah. Gobster, dkk., (2020) lebih berfokus tanah kosong disebabkan oleh tanah terlalu lama diterlantarkan dan adanya aktivitas manusia yang merusak lingkungan. Ardiwijaya, dkk., (2015) juga melihat tanah terlantar sebagai akibat dari faktor lingkungan, institusi, sosial budaya dan ekonomi.

Berbagai problematika yang telah dibahas terkait fenomena penelantaran tanah terutama di Kota Bandar Lampung menjadi cukup menarik untuk dibahas lebih lanjut. Kota Bandar Lampung merupakan salah satu lokasi program Reforma Agraria, dimana tanah terlantar merupakan salah satu objek dari Refoma Agraria. Hak Guna Bangunan di Kota Bandar Lampung sampai dengan Tahun 2020 sebanyak 18.378 bidang tanah. Secara acak diambil 4 (empat) kasus untuk dilakukan penelitian lebih mendalam. Kasus tersebut sangat menarik untuk diulas 
karena beberapa faktor diantaranya adalah peruntukan tanah berbeda-beda, lokasi bidang tanah yang strategis berada di pusat kota dan luas bidang tanah yang diterlantarkan cukup luas. Selain itu motivasi sebagai dorongan atau keadaan dalam diri individu yang menggerakan individu untuk melakukan tindakan penelantaran tanah juga menarik untuk dikaji lebih mendalam. Motivasi tersebut menjadi penyebab-penyebab terjadinya tanah terlantar di perkotaan. Untuk alasan inilah penelitian ini bertujuan untuk mengidentifikasi faktor-faktor yang menyebabkan terjadinya tanah terlantar dari berbagai stakeholder.

\section{Metode}

Metode penelitian yang digunakan dalam penelitian ini adalah metode induktif kualitatif. Unit amatan pada penelitian ini terdiri atas 4 unit amatan yang didasarkan pada lokasi-lokasi terjadinya tanah terlantar terhadap bidang tanah Hak Guna Bangunan Berbadan Hukum atau yang dimiliki coorporate yaitu bidang tanah milik PT. S di Kecamatan Kemiling, bidang tanah milik PT. K di Kecamatan Teluk Betung Selatan, bidang tanah milik PT. WH di Kecamatan Sukarame dan bidang tanah milik PT. WK di Kecamatan Rajabasa. Waktu pelaksanaan pengumpulan data pada penelitian ini dilakukan pada bulan Juli 2019 sampai dengan September 2019 dengan instrumen penelitian adalah peneliti sendiri. Lokasi unit amatan dapat dilihat pada Gambar 1.

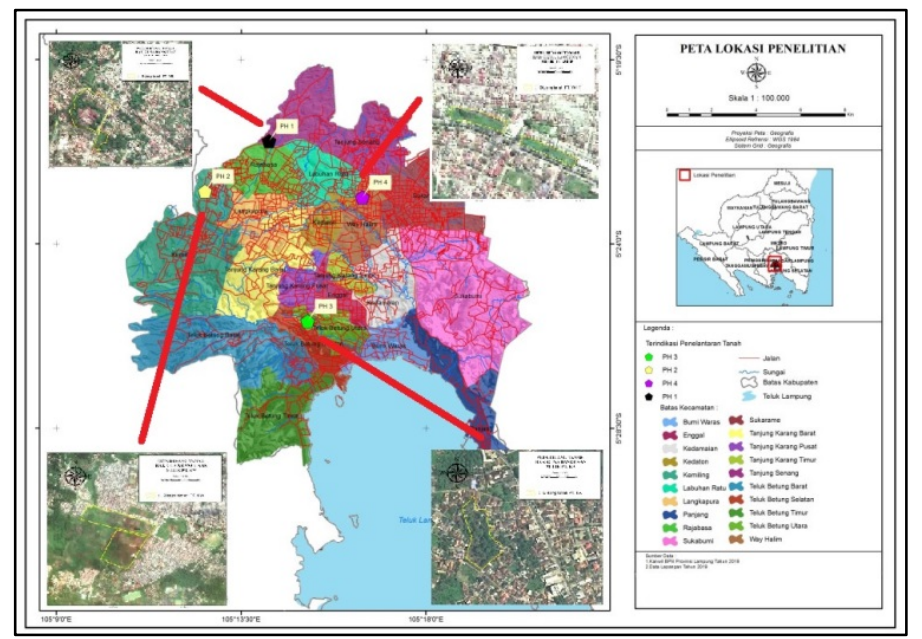

Gambar 1. Lokasi Unit Amatan (Sumber: Analisis, 2020)

\subsection{Metode Pengumpulan Data}

Metode pengumpulan data yang digunakan adalah observasi yaitu mengamati tanah terlantar secara langsung di lapangan, pengumpulan arsip berupa foto-foto bidang tanah yang diterlantarkan, buku-buku dan jurnal penelitian yang meneliti tentang tanah terlantar serta wawancara secara langsung dengan narasumber. Sampel yang dipilih pada penelitian ini adalah narasumber, yang diambil secara purposive sampling. Sampel yang diambil sebanyak 20 narasumber. Pemilihan sampel pada penelitian ini berdasarkan pada keterlibatan dan peran narasumber yaitu narasumber yang terlibat secara langsung dengan tanah terlantar maupun narasumber yang mengetahui tentang tanah terlantar. Uraian lengkap narasumber dapat dilihat pada Tabel 1.

Tabel 1. Narasumber Penelitian

\begin{tabular}{|c|c|c|}
\hline Stakeholder & Kode & Narasumber \\
\hline$(1)$ & $(2)$ & (3) \\
\hline Pemegang Hak/Pemilik & A1 & Manajemen PT. S \\
\hline Tanah/Manajemen yang & $\mathrm{A} 2$ & Manajemen PT. K \\
\hline \multirow[t]{2}{*}{ mewakili } & A3 & Manajemen PT. WH \\
\hline & A4 & Manajemen PT. WK \\
\hline \multirow[t]{4}{*}{ Instansi Pemerintah } & $\mathrm{B} 1$ & $\begin{array}{c}\text { Kepala Seksi Pengendalian Pertanahan, Kanwil BPN Provinsi } \\
\text { Lampung }\end{array}$ \\
\hline & B2 & $\begin{array}{c}\text { Kepala Bagian Infrastruktur dan Pengembangan Wilayah, } \\
\text { Bappeda Kota Bandar Lampung }\end{array}$ \\
\hline & B3 & $\begin{array}{c}\text { Kepala Sub Bagian Otonomi Daerah, Sekretariat Kota Bandar } \\
\text { Lampung }\end{array}$ \\
\hline & B4 & $\begin{array}{c}\text { Kepala Seksi Evaluasi Pemanfaatan Ruang, Dinas Permukiman dan } \\
\text { Tata Ruang Kota Bandar Lampung }\end{array}$ \\
\hline
\end{tabular}




\begin{tabular}{|c|c|c|}
\hline$(1)$ & $(2)$ & (3) \\
\hline \multirow[t]{5}{*}{ Akademisi } & $\mathrm{C} 1$ & Dosen Hukum Pertanahan, Fakultas Hukum, Universitas \\
\hline & $\mathrm{C} 2$ & Lampung \\
\hline & $\mathrm{C} 3$ & Dosen Administrasi Negara, Fakultas Fisipol, Universitas \\
\hline & & Lampung \\
\hline & & Dosen Perencanaan Wilayah Kota, Institut Teknologi Sumatera \\
\hline Media & D1 & Redaktur, Tribun Lampung \\
\hline \multirow[t]{2}{*}{ Pelaku Usaha } & E1 & Manajer PT. Golden Star \\
\hline & E2 & Kepala Legal, PT. Graha Property Center \\
\hline Lembaga Swadaya & F1 & Direktur Walhi Lampung \\
\hline Masyarakat & $\mathrm{F} 2$ & $\begin{array}{l}\text { Direktur Yayasan Lembaga Bantuan Hukum Kota Bandar } \\
\text { Lampung }\end{array}$ \\
\hline \multirow{4}{*}{$\begin{array}{c}\text { Masyarakat yang } \\
\text { memanfaatkan bidang } \\
\text { tanah yang diterlantarkan }\end{array}$} & G1 & Bapak MN, penjaga lingkungan \\
\hline & G2 & Bapak RS, penjaga lingkungan \\
\hline & G3 & Bapak M, pedagang \\
\hline & G4 & Ibu S, ibu rumah tangga \\
\hline
\end{tabular}

Proporsi narasumber diatas, didasarkan pada keterlibatan narasumber baik secara langsung maupun tidak langsung terhadap tanah terlantar dan peran stakeholder terhadap tanah terlantar. Alasan pemilihan sampel diataranya (1) pemegang hak sebanyak 4 narasumber, karena sebagai pemilik tanah terlantar, (2) institusi pemerintahan sebanyak 4 narasumber, karena berperan dalam pengawasan dan pelaksanaan kebijakan terkait pertanahan, (3) akademisi sebanyak 3 narasumber, karena sebagai pemerhati masalah pertanahan (4) media, sebagai pemerhati masalah pertanahan (5) pelaku usaha, sebagai pihak swasta yang terlibat dalam investasi terutama di pertanahan (6) lembaga swadaya masyarakat, selaku pemerhati masalah lingkungan dan pertanahan dan (7) masyarakat di sekitar bidang tanah terlantar, selaku penerima manfaat dari tanah terlantar.

\subsection{Metode Analisis Data}

Data-data yang diperoleh dari pengumpulan data di lapangan selanjutnya dilakukan proses analisis dengan kategorisasi. Proses analisis ini dimulai dari pengumpulan data-data hasil lapangan. Data tersebut diorganisasikan ke dalam dalam kategori-kategori yang memiliki kesamaan tema. Data selanjutnya dijabarkan ke dalam unit-unit informasi dan kemudian unit-unit informasi tersebut dianalisis lebih mendalam. Tahapan selanjutnya, unit-unit informasi disusun ke dalam pola-pola tertentu dan selanjutnya berdasarkan pola-pola tersebut disimpulkan hasil temuan penelitian. Pelaksanaan penelitian ini ditujukan dalam diagram alir pada Gambar 2.

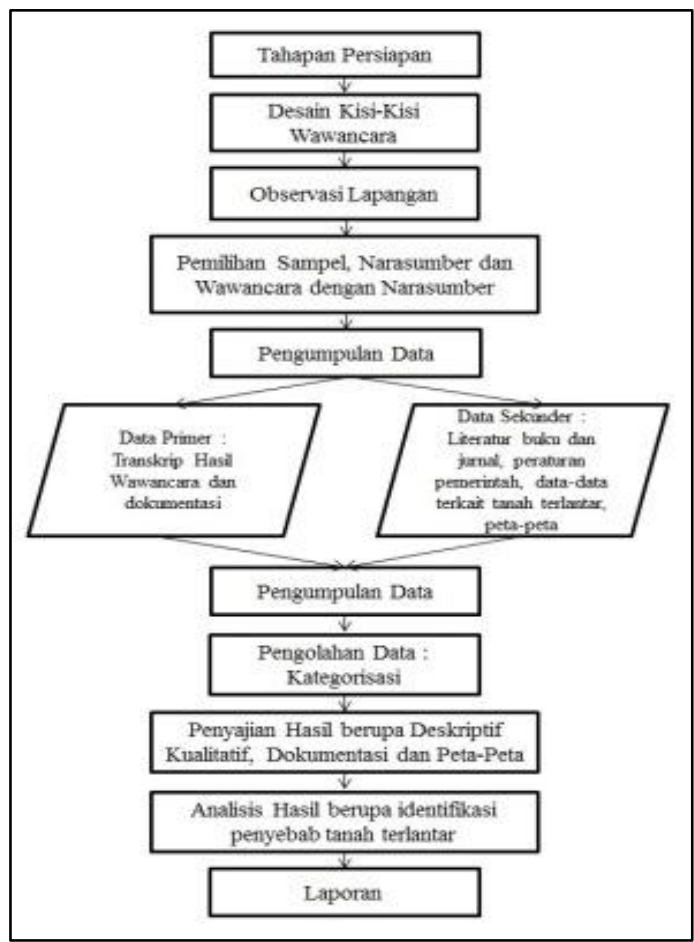

Gambar 2. Diagram Alir Penelitian (Analisis, 2020) 


\section{Hasil dan Pembahasan}

Kota Bandar Lampung memiliki luas wilayah 197,22 $\mathrm{km}^{2}$ yang terbagi dalam 20 Kecamatan serta 126 Kelurahan. Data Pemantauan dan Evaluasi Hak Atas Tanah Tahun 2018 dari Kantor Wilayah BPN Provinsi Lampung, di Kota Bandar Lampung telah dilakukan pemantauan terhadap 133 bidang tanah Hak Guna Bangunan Berbadan Hukum/milik coorporate dengan luas seluruhnya mencapai 260,5 hektar. Dari 133 bidang tanah Hak Guna Bangunan, diduga 30 bidang tanah diterlantarkan akibat belum dimanfaatkan sesuai peruntukannya oleh pemilik tanah. Dari 30 bidang tanah tersebut, dipilih secara acak 4 bidang tanah untuk diteliti lebih lanjut yang tersebar di Kecamatan Kemiling, Kecamtan Rajabasa, Kecamatan Sukarame dan Kecamatan Teluk Betung Selatan.

Pemilihan 4 (empat) bidang tanah untuk dikaji lebih lanjut didasarkan pertimbangan-pertimbangan tertentu yaitu (1) peruntukan tanah berbeda-beda di masing-masing lokasi yaitu bidang tanah di Kecamatan Kemiling untuk perumahan, bidang tanah di Kecamatan Teluk Betung Selatan untuk kantor dan perumahan karyawan, bidang tanah di Kecamatan Rajabasa untuk pabrik serta bidang tanah di Kecamatan Sukarame untuk perdagangan dan jasa, (2) lokasi bidang tanah yang strategis berada di pusat kota, (3) aksesibilitas tanah yang relatif mudah dijangkau, (4) luas bidang tanah yang diterlantarkan cukup luas dan (5) kesediaan pemilik tanah untuk wawancara, karena tidak semua pemilik tanah bersedia untuk diwawancarai.

Hasil penelitian diperoleh dari unit-unit informasi hasil wawancara terhadap 20 narasumber, observasi, studi literatur dan dokumentasi di lapangan. Wawancara secara mendalam pada narasumber bertujuan untuk mengetahui faktor-faktor apa saja yang menjadi penyebab terjadinya tanah terlantar yang dilakukan oleh pemilik tanah. Materi-materi wawancara yang ditanyakan kepada narasumber antara lain (a) bagaimana kondisi tanah atau lingkungan di Kota Bandar Lampung/sekitar tanah yang dimiliki, (b) bagaimana proses terjadinya tanah terlantar di tanah yang dimiliki/di sekitarnya, (c) apa penyebab pemilik tanah menelantarkan tanahnya, (d) siapa saja yang terlibat dalam proses terjadinya tanah terlantar, dan (e) bagaimana upaya yang akan dilakukan/sudah dilakukan dalam menangani terjadinya tanah terlantar.

Dari hasil penelitian, diperoleh unit-unit informasi penyebab terjadinya tanah tanah terlantar berdasar informasi dari berbagai narasumber. Unit-unit informasi tersebut lebih jelas dan detil dapat dilihat pada Tabel 2. Tabel 2 berisi uraian mengenai faktor-faktor penyebab terjadinya tanah terlantar yang dijabarkan sebagai berikut:

\subsection{Ketiadaan dana}

Hasil penelitian diperoleh bahwa ketersediaan dana menjadi faktor mutlak bagi seseorang untuk melakukan pembangunan terhadap tanahnya. Beberapa stakeholder menyatakan motif pemilik tanah tidak bisa membangun disebabkan ketiadaan uang sebagai modal untuk membangun. Tidak semua tanah dibeli secara tunai, beberapa diperoleh dengan cara kredit. Hal ini diakibatkan iklim perekonomian Indonesia secara global tidak baik, ditandai dengan tingginya harga tanah (Sumardjono, 2009). Tingginya harga tanah menjadi penyebab banyak pemegang hak cenderung membeli tanah dengan cara kredit. Semakin besar perolehan kredit maka semakin besar nominal bunga bank yang harus dipenuhi. Keharusan membayar bunga bank yang tinggi sangat memberatkan investor untuk mengelola finansial perusahannya. Kebutuhan membayar bunga yang tinggi tersebut tidak sebanding dengan keuntungan finansial yang diperoleh pelaku usaha. Akibatnya, beberapa investor selalu mengalami kerugian karena terpaksa harus membayar kekurangan bunga bank. Kerugian-kerugian yang timbul ini menjadi menjadi alasan pemegang hak lebih memprioritaskan kebutuhan finansialnya untuk membayar bunga bank daripada untuk membangun. Pemilik tanah yang tidak mampu membayar pinjaman beserta bunga yang diwajibkan oleh pihak bank, berdampak kredit macet dan mengalami gagal bayar. Akibat ketidakmampuan tersebut, tanah yang dimiliki oleh pemegang hak tidak dapat dilanjutkan lagi pembangunannya sehingga menjadi tanah terlantar.

\subsection{Konflik antar pihak dalam keluarga akibat ketidaksepakatan masalah warisan}

Tidak hanya masalah dana, adanya konflik antar pihak dalam keluarga akibat ketidaksepakatan masalah warisan menjadi alasan pemegang hak belum memanfaatkan tanahnya. Temuan di lapangan, konflik internal antar anggota keluarga berpangkal dari minimnya komunikasi yang berujung pada ketidaksepahaman antara anggota keluarga. Akibatnya pemanfaatan tanah tidak lagi menjadi prioritas bagi manajemen perusahaan namun lebih berfokus penyelesaian konflik internal keluarga. Perebutan hak waris menjadi persoalan pelik yang berujung pada tindakan penelantaran tanah oleh pemegang hak. Bidang tanah dibiarkan terlantar dan tidak dimanfaatkan oleh seluruh ahli waris sampai batas waktu kesepakatan pembagian hak waris disepakati bersama.

\subsection{Spekulasi untuk memperoleh keuntungan}

Adanya motif pemegang hak berspekulasi untuk memperoleh keuntungan menjadi alasan pemegang hak belum memanfaatkan tanahnya. Tanah dinilai sebagai jaminan investasi karena mampu menghasilkan keuntungan finansial. Pemilik tanah sengaja membeli tanah agar di masa mendatang, harga tanah menjadi jauh lebih tinggi dibandingkan saat pembelian. Selain itu pemegang hak belum memanfaatkan tanahnya karena menunggu pembeli 
Tabel 2. Unit-Unit Informasi Penyebab Terjadinya Tanah Terlantar

\begin{tabular}{|c|c|c|}
\hline $\begin{array}{c}\text { Penyebab } \\
\text { Tanah Terlantar }\end{array}$ & $\begin{array}{c}\text { Nara } \\
\text { sumber }\end{array}$ & Unit-Unit Informasi \\
\hline \multirow[t]{7}{*}{ Ketiadaan Dana } & $\mathrm{A} 2$ & Terbentur masalah ketiadaan dana, sehingga belum dibangun \\
\hline & A3 & $\begin{array}{l}\text { Ingin membangun namun tidak memiliki modal sehingga meminjam modal ke } \\
\text { perbankan. }\end{array}$ \\
\hline & $\mathrm{C} 1$ & $\begin{array}{l}\text { Ingin membangun namun sulit karena tidak memiliki akses terhadap } \\
\text { perbankan }\end{array}$ \\
\hline & B1 & $\begin{array}{l}\text { Kredit macet karena idak mampu membayar angsuran peminjaman modal ke } \\
\text { perbankan, sehingga tidak mampu membangun }\end{array}$ \\
\hline & G2 & Belum membangun tapi karena pemilik tanah tidak punya biaya lagi \\
\hline & G3 & Sepertinya pemilik tanah tidak lagi punya uang untuk membangun \\
\hline & G4 & Usaha sudah tidak berjalan karena pemilik tidak memiliki uang \\
\hline \multirow{4}{*}{$\begin{array}{c}\text { Konflik antar } \\
\text { pihak dalam } \\
\text { keluarga akibat } \\
\text { ketidaksepakatan } \\
\text { masalah warisan }\end{array}$} & A1 & $\begin{array}{l}\text { Karena warisan yang banyak, ahli waris juga banyak sehingga ada yang setuju } \\
\text { untuk dibangun namun ada yang menentang }\end{array}$ \\
\hline & A4 & $\begin{array}{l}\text { Ini adalah perusahaan keluarga, jadi konflik keluarga pasti mempengaruhi } \\
\text { belum dilanjutkannya usaha ini }\end{array}$ \\
\hline & B4 & Ada konflik internal di keluarga sendiri \\
\hline & G1 & Belum dibangun karena masalah keluarga pemilik tanah \\
\hline \multirow{5}{*}{$\begin{array}{l}\text { Spekulasi untuk } \\
\text { memperoleh } \\
\text { keuntungan }\end{array}$} & $\mathrm{C} 2$ & $\begin{array}{l}\text { Sangat rasional jika pemilik tanah mencari keuntungan, jika salah satu } \\
\text { kegiatan dianggap lebih menguntungkan }\end{array}$ \\
\hline & $\mathrm{C} 1$ & $\begin{array}{l}\text { Belum dibangun karena sengaja mencari keuntungan, pemilik berspekulasi } \\
\text { jika tahun berrikutnya harganya akan naik }\end{array}$ \\
\hline & E1 & $\begin{array}{l}\text { Pemilik berspekulasi menunggu pembeli, tidak ingin merugi jika segera } \\
\text { dibangun }\end{array}$ \\
\hline & $\mathrm{F} 1$ & Ingin bermain di jual beli alas hak, sengaja mencari untung \\
\hline & $\mathrm{F} 2$ & $\begin{array}{l}\text { Sengaja mengkolapskan perusahaan, agar tidak memberikan ganti rugi } \\
\text { pembebasan tanah, sehingga bisa mendapat untung dari agunan bank }\end{array}$ \\
\hline \multirow{2}{*}{$\begin{array}{l}\text { Perusahaan } \\
\text { bangkrut }\end{array}$} & D1 & Perusahaan mengalami wanprestasi dan mengalami kebangkrutan \\
\hline & $\mathrm{F} 2$ & $\begin{array}{l}\text { Perusahaan bangkrut karena perusahaan tidak mampu memanajemen } \\
\text { perusahaan dengan baik }\end{array}$ \\
\hline $\begin{array}{c}\text { Kesalahan } \\
\text { identifikasi } \\
\text { pangsa pasar }\end{array}$ & E2 & $\begin{array}{l}\text { Awalnya tanah dimanfaatkan untuk pengembangan perumahan namun akibat } \\
\text { salah memprediksi pangsa pasar, mengakibatkan perusahaan berhenti } \\
\text { membangun }\end{array}$ \\
\hline \multirow{5}{*}{$\begin{array}{l}\text { Ketidaksesuaian } \\
\text { Hak Atas Tanah } \\
\text { dengan Rencana } \\
\text { Tata Ruang }\end{array}$} & A4 & $\begin{array}{l}\text { Peruntukan harusnya untuk kawasan pendidikan dan pemukiman, sedangkan } \\
\text { untuk pabrik tidak diperbolehkan }\end{array}$ \\
\hline & $\mathrm{C} 1$ & Tidak memanfaatkan karena tata ruang tidak sesuai lagi dengan peruntukan \\
\hline & $\mathrm{F} 2$ & Penelantaran terjadi akibat perubahan kebijakan tata ruang \\
\hline & E2 & Ingin membangun tidak bisa karena sebagai zone merah \\
\hline & $\mathrm{C} 3$ & $\begin{array}{l}\text { Memanfaatkan tanah harus patuh dan sesuai dengan tata ruang, ada } \\
\text { konsekuensi jika tidak sesuai dengan tata ruang }\end{array}$ \\
\hline \multirow{2}{*}{$\begin{array}{l}\text { Kesalahan } \\
\text { analisis } \\
\text { kelayakan } \\
\text { pemberian hak }\end{array}$} & B4 & $\begin{array}{l}\text { Lokasi tanah masuk dalam kawasan pergudangan, namun karena } \\
\text { ketidaklengkapan dokumen mengakibatkan kesalahan identifikasi pemberian }\end{array}$ \\
\hline & & hak \\
\hline $\begin{array}{l}\text { Ketidaktegasan } \\
\text { minimum waktu } \\
\text { pembangunan }\end{array}$ & $\mathrm{C} 1$ & $\begin{array}{l}\text { Terjadi penelantaran tanah karena batas waktu pembangunan yang tidak jelas } \\
\text { dan tegas }\end{array}$ \\
\hline \multirow{4}{*}{$\begin{array}{l}\text { Konflik pemilik } \\
\text { tanah dengan } \\
\text { masyarakat dan } \\
\text { perusahaan } \\
\text { lainnya }\end{array}$} & D1 & Belum membangun karena ada konflik dengan masyarakat sekitar \\
\hline & $\mathrm{F} 2$ & Diterlantarkan karena pemilik tanah konflik dengan masyarakat \\
\hline & $\mathrm{F} 1$ & $\begin{array}{l}\text { Tanah masih kosong karena dikuasai oleh masyarakat, masih tumpang tindih } \\
\text { kepemilikan pengakuan antara masyarakat dengan perusahaan }\end{array}$ \\
\hline & D1 & $\begin{array}{l}\text { Tanah diklaim kepemilikannya oleh perusahaan lain, sehingga dibandingkan } \\
\text { dibangun lebih baik tanah dibiarkan terlantar sampai ada penyelesaian } \\
\text { terhadap kepemilikan tanah }\end{array}$ \\
\hline \multirow{3}{*}{$\begin{array}{c}\text { Politik } \\
\text { Pemerintah }\end{array}$} & F2 & Secara politik,pemerintah tidak mau memberi ketegasan sehingga jadi \\
\hline & & terlantar, karena proses politik yang tidak meneruskan kebijakan sebelumnya \\
\hline & $\mathrm{C} 2$ & $\begin{array}{l}\text { Penelantaran tanah tidak lepas dari aspek politik, anggarannya tidak } \\
\text { mendukung kebijakan sebelumnya sehingga tanah dibiarkan terlantar }\end{array}$ \\
\hline
\end{tabular}


dibandingkan harus membangun tanahnya saat ini dengan konsekuensi harga jual kurang menguntungkan. Jika tanah sudah dibangun sebagai rumah ataupun tempat usaha memiliki nilai jual yang rendah apalagi sudah dibangun cukup lama. Akibatnya, pemegang hak menunggu pembeli yang berminat investasi di tanah tersebut kemudian dibangun, dibandingkan pemegang hak harus membangun tanahnya dengan resiko biaya perawatan dan kerusakan bangunan yang tinggi. Pemilik tanah belum membangun tanahnya diduga ada permainan jual beli alas hak. Oknum perseorangan sengaja membeli tanah dilokasi yang cukup strategis, namun tidak segera dibangun. Oknum tersebut sengaja menawarkan tanahnya dengan harga yang jauh lebih tinggi. Pencari tanah yang tidak ingin berurusan dengan masalah administrasi yang rumit, akan lebih memilih tanah tersebut untuk dibeli dengan konsekuensi harga beli jauh lebih tinggi di pasaran namun administrasi sudah clear and clean. Hal tersebut merupakan celah bagi oknum tersebut untuk mencari keuntungan dari proses jual beli alas hak.

\subsection{Perusahaan bangkrut}

Alasan lainnya pemegang hak menelantarkan tanah karena pemegang hak mengalami wanprestasi atau bangkrut. Gagalnya usaha yang dijalankan oleh pemegang hak berakibat kerugian finansial yang berujung pada kolapsnya perusahaan. Pailitnya perusahaan akibat ketidakmampuan perusahaan memanajemen perusahaan secara sehat dan baik. Awalnya pemegang hak memanfaatkan tanah sudah sesuai dengan peruntukannya, namun sering waktu akibat manajemen perusahaan yang tidak baik karena kemampuan Sumberdaya Manusia yang rendah dan daya saing antar perusahaan yang sangat tinggi mengakibatkan perusahaan mengalami kerugian finansial. Pendapatan perusahaan tidak lagi mampu menutupi biaya operasional perusahaan seperti pengeluaran untuk gaji karyawan, biaya perawatan barang-barang milik perusahaan, biaya perawatan bangunan, biaya promosi dan biaya-biaya lain berujung pada penutupan usaha. Penutupan usaha tersebut berakibat pada tidak beroperasionalnya penggunaan tanah dan menyebabkan tanah terlantar.

\subsection{Kesalahan identifikasi pangsa pasar}

Motif lainnya adalah kesalahan pemegang hak dalam identifikasi pangsa pasar. Pasar tanah sangat tergantung pada permintaan dan penawaran. Dalam menjalankan usahanya, seharusnya pemilik tanah dapat memperhitungkan keadaan pasar, apakah investasi yang telah digelontorkan memiliki keuntungan atau justru sebaliknya. Minimnya informasi dan ketidakjelian melihat potensi pasar berakibat pada kesalahan dalam memperhitungkan prospek keuntungan. Akibat kesalahan identifikasi tersebut, berakibat pada kerugian materiil yaitu harga tanah yang dimiliki akan jatuh sehingga oleh pemilik tanah tanah dibiarkan terbengkalai. Sikap pemegang hak cenderung membiarkan dan tidak memanfaatkan tanahnya sampai kondisi pasar memungkinkan memberikan keuntungan di masa akan datang menyebabkan tanah menjadi terlantar.

\subsection{Ketidaksesuaian hak atas tanah dengan Rencana Tata Ruang akibat perubahan kebijakan tata ruang}

Hasil penelitian ditemukan bahwa pemilik tanah belum membangun karena adanya ketidaksesuaian hak atas tanah dengan Rencana Tata Ruang Wilayah sehingga menjadikan pemanfaatan tanah tidak sesuai dengan peruntukan tanahnya. Perubahan kebijakan terutama kebijakan tentang Rencana Tata Ruang Wilayah, disesuaikan dengan kondisi pemanfaatan tanah saat ini. Namun hal tersebut berimbas pada beberapa hak atas tanah yang harus menyesuaikan terhadap aturan tata ruang tersebut. Penggunaan dan pemanfaatan tanah saat ini tidak sesuai dengan Rencana Tata Ruang dapat dilihat pada Gambar 3.

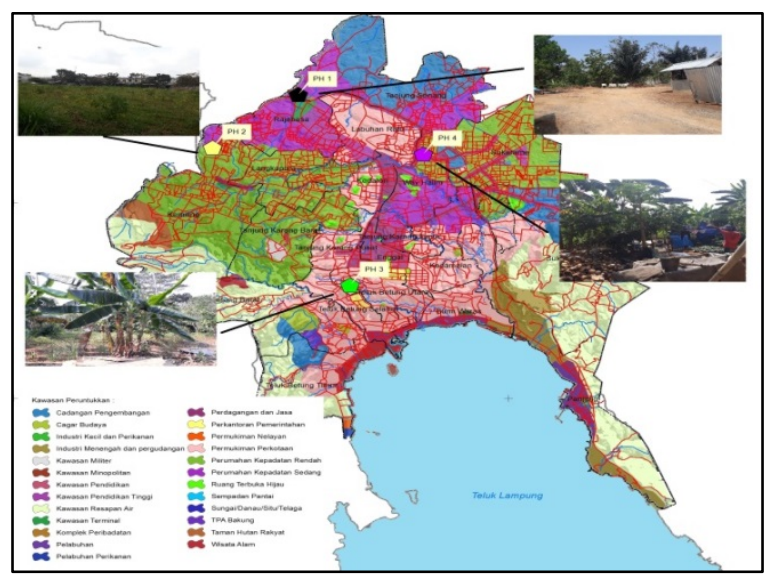

Gambar 3. Penggunaan dan pemanfaatan tanah saat ini tidak sesuai dengan Rencana Tata Ruang (Sumber: Dipetakan berdasarkan Data Hak Atas Tanah, dari Aplikasi Komputerisasi Kegiatan Pertanahan dan Dokumentasi Lapangan, 2020) 
Gambar diatas menunjukkan beberapa bidang tanah Hak Guna Bangunan yang dimiliki coorporate, tidak sesuai dengan Rencana Tata Ruang Kota Bandar Lampung. Aturan pemberian hak atas tanah terutama Hak Guna Bangunan yang tertuang dalam Peraturan Menteri Negara Agraria/Kepala BPN Nomor 9 Tahun 1999 harusnya tanah digunakan sesuai peruntukan tanah yang diatur dalam. Observasi terhadap bidang-bidang tanah milik PT. S di Kecamatan Kemiling, di Surat Keputusan Pemberian Hak oleh Badan Pertanahan Nasional, harusnya bidang tanah dimanfaatkan untuk perumahan, namun oleh pemilik tanah tidak dimanfaatkan sebagai apapun, masih berupa tanah kosong. Sama halnya dengan bidang tanah milik PT. K, bahwa dalam Surat Keputusan Pemberian Hak, bidang tanah harusnya dimanfaatkan untuk perkantoran namun oleh pemilik tanah belum dibangun untuk perkantoran. Beberapa bidang tanah juga terindentifikasi milik PT. WH tidak dimanfaatkan untuk perdagangan dan jasa, namun dibiarkan terbengkalai oleh pemilik tanah. Bidang tanah lainnya milik PT. WK di Kecamatan Rajabasa, oleh pemilik tanah tidak dimanfaatkan untuk pabrik dengan alasan tidak sesuai lagi dengan Rencana Tata Ruang. Dahulu, peruntukan tanah yang tercantum dalam SK pemberian hak sesuai dengan Rencana Tata Ruang yaitu sebagai kawasan industri Namun saat ini, kawasan tersebut berubah menjadi kawasan permukiman dan pendidikan akibat perkembangan kota yang semakin meluas ke wilayah pinggiran. Akibatnya, pabrik dibiarkan tidak beroperasi dan dibiarkan terbengkalai.

Hasil observasi dan kajian literatur diperoleh bahwa setelah dilakukan pengecekan terhadap Surat Keputusan Pemberian Hak Guna Bangunan bidang-bidang tanah milik beberapa coorporate yang dikeluarkan oleh Badan Pertanahan Nasional, dengan Rencana Tata Ruang Kota Bandar Lampung berdasar Peraturan Daerah Kota Bandar Lampung Nomor 10 Tahun 2011, maka terdapat ketidaksesuaian bidang-bidang tanah tersebut dengan Rencana Tata Ruang Kota Bandar Lampung. Ketidaksesuaian tersebut bertentangan dengan Peraturan Menteri Negara Agraria/Kepala BPN Nomor 9 Tahun 1999 dalam pasal 34, setiap permohonan Hak Guna Bangunan harus menyertakan ijin penunjukkan penggunaan tanah sesuai dengan tata ruang.

\subsection{Kesalahan dalam menganalisis kelayakan pemberian hak atas tanah}

Kesalahan analisis kelayakan pemberian hak dapat menyebabkan pemberian hak atas tanah tidak sesuai dengan peruntukannya. Hal tersebut berimbas pada tertundanya pembangunan hak atas tanah. Lokasi sudah sesuai dengan peraturan zonasi, namun terkadang informasi yang diberikan oleh pemilik tanah tidak sesuai dengan administrasi yang ditentukan. Beberapa dokumen-dokumen sengaja diubah agar memenuhi persyaratan kelayakan pemberian hak sehingga terjadi kesalahan dalam analisis kelayakan pemberian ijin terhadap hak atas tanah. Kesalahan analisis tersebut berakibat ijin kelayakan pemberian hak atas tanah cacat hukum sehingga bidang tanah yang sedianya dimohonkan untuk dibangun, dibiarkan terbengkalai oleh pemilik tanah sampai waktu ijin kelayakan pemberian hak diperoleh kembali.

\subsection{Ketidaktegasan waktu minimum pembangunan}

Ketidaktegasan batas waktu minimum pembangunan dapat menyebabkan terjadinya penelantaran tanah. Pemerintah harusnya memberikan batas waktu minimum yang tegas terkait pembangunan hak atas tanah agar tidak terjadi penelantaran tanah. Pemegang hak telah membangun tanahnya sesuai dengan peruntukan, yaitu untuk perumahan. Namun pembangunan hanya sebatas tampilan fisik luar bangunan saja, sedangkan fisik didalamnya belum dibangun. Hal ini sengaja dilakukan oleh pemilik tanah karena pemerintah tidak menerapkan batas waktu penyelesaian bangunan secara tegas. Pemegang hak sengaja mengulur-ulur waktu pembangunan mengakibatkan tanah tidak bermanfaat secara optimal karena bangunan belum dapat digunakan dan dimanfaatkan.

\subsection{Konflik dengan masyarakat dan perusahaan lainnya}

Hasil penelitian menemukan bahwa penyebab pemilik tanah menelantarkan tanahnya timbul karena konflik dengan masyarakat maupun konflik dengan perusahaan lainnya. Ketidaksepahaman antara masyarakat maupun pelaku usaha lainnya sebagai cikal bakal timbulnya pertentangan antara pihak-pihak yang merasa saling dirugikan. Pertentangan yang tidak mencapai titik terang tersebut berujung di ranah hukum pengadilan sebagai solusi terhadap penyelesaian masalah pertanahan.

Motif yang diungkap oleh stakeholder adalah adanya konflik dengan masyarakat, salah satunya masalah ganti rugi lahan yang tidak sesuai. Proses ganti rugi oleh pemilik tanah kepada masyarakat tidak menemui kesepakatan terutama dalam biaya ganti rugi lahan menjadikan masyarakat menduduki lahan sebagai bentuk protes terhadap pemilik tanah. Akibatnya perusahaan tidak mampu membangun tanahnya sesuai pemberian haknya karena pendudukan tanah oleh masyarakat. Selain itu terjadi penyerobotan tanah oleh masyarakat karena melihat lokasi tanah yang stategis menjadikan pemilik tanah tidak mampu membangun dan memanfaatkan tanahnya. Masyarakat menduduki tanah untuk kegiatan pertanian, perdagangan maupun bermukim. Akibatnya pemilik tanah sulit untuk mengusir masyarakat dengan alasan harus ada ganti rugi terhadap bangunan diatas tanah. Kondisi tersebut sangat memberatkan, pemilik tanah lebih membiarkan tanah tetap diduduki oleh masyarakat sampai batas waktu tidak ditentukan. Klaim-klaim atas penguasaan tanah oleh perusahaan lain timbul akibat ketidaksempurnaan proses 
pemilikan tanah sehingga berakibat tumpang tindih kepemilikan hak tanah akibat proses kepemilikan tanah yang tidak clear and clean. Beberapa dokumen kepemilikan tanah diperoleh secara tidak sah, atau tidak sesuai dengan prosedur dan aturan yang telah ditetapkan. Sehingga pemegang hak merasa sebagai pemilik sah atas tanah yang dimiliki. Pengadilan menjadi satu-satunya solusi yang dianggap mampu menyelesaikan konflik antar pemegang hak tersebut sehingga sampai keputusan pengadilan diperoleh, hak atas tanah dibiarkan terlantar oleh pemegang hak sampai batas waktu mencapai kesepakatan bersama.

\subsection{Belum membangun karena politik pemerintahan}

Alasan pemegang hak belum memanfaatkan dan menelantarkan tanahnya yang disampaikan oleh narasumber adalah akibat politik pemerintahan. Politik pemerintahan yang selalu berubah-ubah, tergantung perubahan iklim politik negara menjadikan beberapa kebijakan tidak berjalan maksimal sehingga pengawasan dan pengendalian terhadap hak atas tanah tidak terkoordinasi optimal.

Dari unit-unit informasi yang diperoleh sebelumnya, banyak faktor-faktor yang melatarbelakangi terjadinya tindakan penelantaran tanah. Faktor terbesar yang menjadi latar belakang tindakan penelantaran tanah oleh pemilik tanah adalah ketiadaan dana pemilik tanah untuk membangun tanahnya sesuai penggunaan dan pemanfaatan yang dimohonkan sebelumnya. Gambaran mengenai komposisi jumlah narasumber dengan penyebab tanah terlantar dapat dilihat pada Gambar 4.

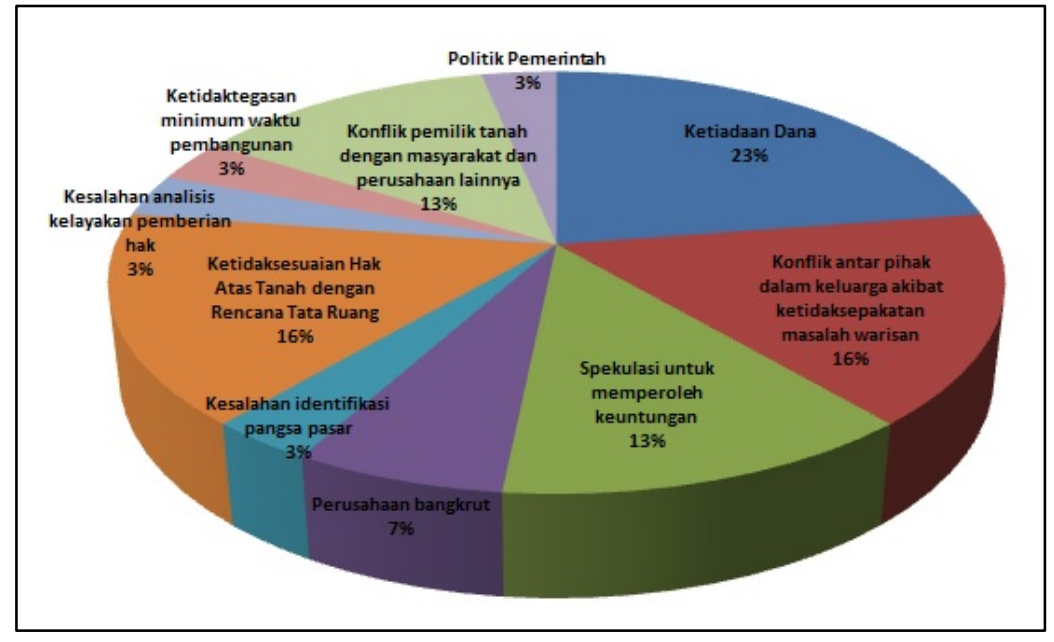

Gambar 4. Diagram Alir Penelitian (Analisis, 2020)

Gambar diatas menunjukan bahwa tanah terlantar disebabkan karena ketiadaan uang pemilik tanah untuk membangun hak atas tanah yang dimilikinya disampaikan oleh 7 narasumber, spekulasi untuk memperoleh keuntungan disampaikan oleh 5 narasumber, konflik antar pihak dalam keluarga akibat ketidaksepakatan masalah warisan disampaikan 4 narasumber, perusahaan bangkrut disampaikan oleh 2 narasumber, kesalahan identifikasi pangsa pasar disampaikan oleh 1 narasumber, ketidaksesuaian hak atas tanah dengan Rencana Tata Ruang yang disampaikan oleh 5 narasumber, kesalahan analisis kelayakan pemberian hak disampaikan oleh 1 narasumber, ketidaktegasan minimum waktu pembangunan disampaikan oleh 1 narasumber, konflik pemilik tanah dengan masyarakat dan perusahaan lainnya yang disampaikan oleh 4 narasumber, dan politik pemerintah disampaikan oleh 2 narasumber.

Merujuk pada Undang-Undang Pokok Agraria, bahwa hak guna bangunan akan dicabut haknya jika diterlantarkan sebenarnya bentuk dari ketegasan pemerintah terhadap pelanggaran-pelanggaran pemanfaatan yang terjadi di lingkup masyarakat. Namun hendaknya aturan ini harus diimbangi dengan pengawasan dan pengendalian terhadap penyimpangan-penyimpangan yang mungkin terjadi di lapangan. Sektoralisasi pengaturan tentang masalah pertanahan menjadi penghambat dalam mewujudkan masyarakat yang berkeadilan (Mujiburohman, 2019). Perlu kesadaran, dukungan bagi seluruh elemen-elemen masyarakat dari tingkat bawah yaitu pemilik tanah, masyarakat, manajemen pertanahan maupun pemerintah dalam mengatasi persoalan tanah terlantar. Dukungan dari elit penguasa dengan mendukung seluruh kebijakan dalam pengawasan dan pengendalian terhadap hak atas tanah diharapkan mampu mengatur perilaku pemilik tanah untuk memanfaatkan tanahnya sesuai peruntukan sehingga tidak terjadi tindakan penelantaran tanah. Dalam penyusunan regulasi kebijakan daerah, hendaknya mempertimbangkan aspek pertanahan yang meliputi aspek penguasaan dan penggunaan tanahnya dengan mementingkan kepentingan daerah (Ilmiawan, 2016). Kebijakan pemerintah harus tegas dan adil agar tidak terjadi tindakan penelantaran tanah oleh masyarakat, swasta maupun pemerintah sendiri. Apapun wujud 
perubahan kebijakan dalam tata ruang senantiasa memprioritaskan aspek pertanahan, sehingga tetap mampu mengakomodasi seluruh kepentingan masyarakat bersama

Dari hasil penelitian, telah diidentifikasi faktor-faktor yang menyebabkan terjadinya tanah terlantar di Kota Bandar Lampung sesuai dengan tujuan penelitian. Faktor-faktor penyebab terjadinya tanah terlantar dapat dikelompokkan berdasarkan kesamaan motif penyebab terjadinya tanah terlantar. Hasil penelitian ditemukan 3 (tiga) faktor-faktor utama yaitu :

1. Faktor Ekonomi

Dari beberapa faktor-faktor yang ditemukan, bahwa faktor ekonomi menjadi faktor yang paling dominan sebagai penyebab terjadinya tanah terlantar. Faktor-faktor ekonomi tersebut diantaranya adalah (a) ketiadaan dana pemegang hak untuk membangun, (b) spekulasi pemegang hak mencari keuntungan, (c) perusahaan bangkrut, dan (d) kesalahan identifikasi pangsa pasar.

2. Faktor Institusi

Selain faktor ekonomi, faktor institusi juga menjadi faktor penyebab terjadinya tanah terlantar di perkotaan. Faktor-faktor institusi tersebut diantaranya adalah (a) ketidaksesuaian hak atas tanah dengan Rencana Tata Ruang akibat perubahan kebijakan tata ruang, (b) kesalahan analisis kelayakan pemberian hak, (c) ketidaktegasan minimum waktu pembangunan, dan (d) politik pemerintahan .

3. Faktor Sosial-Hukum

Faktor sosial dan hukum juga menjadi penyebab terjadinya tanah terlantar. Faktor-faktor sosial dan hukum diantaranya (a) ada konflik antar pihak dalam keluarga akibat ketidaksepakatan masalah warisan, dan (b) konflik dengan masyarakat dan perusahaan lainnya

\section{Kesimpulan}

Dari hasil penelitian, dapat ditarik kesimpulan bahwa faktor-faktor yang menyebabkan terjadinya tanah terlantar di Kota Bandar Lampung adalah :

1. Faktor Ekonomi, penyebab terjadinya tanah terlantar faktor ekonomi didominasi oleh ketiadaan dana pemilik tanah untuk membangun tanah sesuai dengan pemberian haknya.

2. Faktor Institusi, penyebab terjadinya tanah terlantar faktor institusi didominasi oleh ketidaksesuaian pemberian hak atas tanah dengan tata ruang.

3. Faktor Sosial-Hukum, penyebab terjadinya tanah terlantar faktor sosial-hukum didominasi oleh konflik dengan masyarakat dan perusahaan lainnya.

Diharapkan temuan ini dapat menjadi edukasi bagi pemerintah agar menjadikan tindakan penelantaran tanah oleh pemegang hak sebagai tindakan yang perlu perhatian khusus agar tidak lagi ditemui tanah-tanah terlantar. Pemerintah diharapkan dapat membuat kebijakan yang mampu mengakomodasi seluruh kepentingan masyarakat, swasta maupun pemerintah sendiri sehingga mampu mewujudkan tanah untuk keadilan dan kesejahteraan rakyat.

\section{Ucapan Terima Kasih}

Artikel ini hasil penelitian tesis di Magister Perencanaan Wilayah dan Kota, Fakultas Teknik, Universitas Gadjah Mada. Peneliti mengucapkan terimakasih kepada Pusat Pembinaan, Pendidikan dan Pelatihan Perencanaan Bappenas (Pusbindiklatren Bappenas) selaku pihak pemberi beasiswa. Ucapan terimakasih juga dipersembahkan kepada seluruh komunitas akademik Universitas Gadjah Mada, Kementerian Agraria dan Tata Ruang/Badan Pertanahan Nasional, Pemerintah Daerah Kota Bandar Lampung, dan pihak-pihak lainnya yang membantu pelaksanaan penelitian ini.

\section{Daftar Pustaka}

Ardiwijaya VS, Sumardi TP, Suganda E, Temenggung Y. (2015). "Bandung urban sprawl and idle land: spatial environment perspectives". International Conference of Environmetnal Science and Development (ICESD) 2014. Singapore : 19-21 February 2014

Gao, Y. \& Ma, Y. (2015). "What is Absent from The Current Monitoring : Idleness of Rural Industrial Land in Suburban Shanghai". Published by Elsevier Ltd. Habitat International 49 (2015) 138-147

Gobster, P. H., Hadavi, S., Rigolon, A., \& Stewart, W.P. (2020). Measuring Landscape change lot by lot : Greening, activity in response to a vacant land reuse program. Lanscape and Urban Planning,196. Desember 2019.

Ilmiawan. (2016). "Analisis Faktor Penyebab Tanah Terlantar di Daerah Transmigrasi Desa Waode Angkalo Kabupaten Buton Utara". Tesis. Program Pascasarjana Fakultas Teknik. Universitas Gadjah Mada. Yogyakarta

Li,Y. (2014). "Study on Idle land in China's Rural Areas". International Conference on Advanced Information and Comunication Technology for Education (ICAICTE)

Mujiburohman, D.A. (2019). "Penegakan Hukum Penertiban dan Pendayagunaan Tanah Terlantar". Penerbit STPN Press. Yogyakarta 
Republik Indonesia, (1960), “Undang-Undang Nomor 5 Tahun 1960 tentang Peraturan Dasar Pokok-pokok Agraria”. Lembaran Negara RI Tahun 1960, No. 104, Sekretariat Negara, Jakarta. Republik Indonesia, (1999), "Peraturan Menteri Negara Agraria/Kepala BPN Nomor 9 Tahun 1999 tentang Tata Cara Pemberian Hak Atas Negara dan Hak Pengelolaan. Jakarta.

Republik Indonesia, (2010), "Peraturan Pemerintah Republik Indonesia Nomor 11 Tahun 2010 tentang Penertiban dan Pendayagunaan Tanah Terlantar". Lembaran Negara RI Tahun 2010, No. 61, Sekretariat Negara, Jakarta.

Republik Indonesia, (2010), "Peraturan Kepala Badan Pertanahan Nasional Republik Indonesia Nomor 1 Tahun 2010 tentang Standar Pelayanan dan Pengaturan Pertanahan”. Badan Pertanahan Nasional RI, Jakarta

Sumardjono, Maria, S.W. (2009). "Tanah dalam Perspektif Hak Ekonomi, Sosial dan Budaya”. Penerbit Buku Kompas. Jakarta 